\title{
Parkinson's Disease and Headache
} Parkinson Hastalı̆̆ı ve Baş A ğrısı

\author{
Halil Murat Şen1, Tuğba Oruç Tunç², Levent Ertuğrul İnan 3 \\ ${ }^{1}$ Çanakkale 18 Mart University Medical School, Çanakkale, Turkey \\ ${ }^{2}$ Gazi University Medical School, Ankara, Turkey \\ ${ }^{3}$ Ankara Training and Research Hospital, Ankara, Turkey
}

\section{Summary}

Objective: The etiology and frequency of headache complaint were examined in patients diagnosed with idiopathic Parkinson's disease.

Materials and Methods: 60 patients diagnosed with idiopathic Parkinson's disease in policlinic and a healthy control group of 100 people of similar age and sex were included in the study.

Results: Headache was found in 26 of the patients (43.3\%) with idiopathic Parkinson's disease. There was not a significant difference between the ages of patients with and without headache. The duration of the disease was significantly longer in the patients without headache when compared to those with headache.

Conclusion: The frequency of headache in patients with idiopathic Parkinson's disease is not higher than the healthy population. (Turkish Journal of Neurology 2014; 20:36-8)

Key Words: Parkison's disease, headache, tension-type headache

\section{Özet}

Amaç: İdiopatik Parkinson hastalığı tanısı ile izlenen hastalarda baş ağrısı yakınmasının etiyolojisi ve sıklığı incelendi.

Gereç ve Yöntem: Çalışmaya polikliniğimizde idiopatik Parkinson hastalığı tanısı alan 60 hasta ve kontrol grubu olarak benzer yaş ve cinsiyette 100 sağlıklı kişi dahil edildi. Bulgular: İdiopatik Parkinson hastalığının 26'sında $(\% 43,3)$ baş ağrısı saptandı. Baş ağrısı olan ve olmayan hastaların yaşları arasında anlamlı bir fark yoktu. Hastalığın süresi, baş ağrısı olmayan hastalarda baş ağrısı olanlarla karşılaşıtırıldığında anlamlı derecede uzun bulundu.

Sonuç: İdiopatik Parkinson hastalığında baş ağrisı sıklı̆̆ı, sağlıklı popülasyondan fazla değildir. (Türk Nöroloji Dergisi 2014; 20:36-8)

Anahtar Kelimeler: Parkinson hastalı̆̆ı, baş ağrısı, gerilim tipi baş ağrısı

\section{Introduction}

Headache is the most common disorder of the nervous system and its certain subtypes affect the daily life profoundly (1). Clinical studies have shown that headaches affect both the person suffering it and the society at large (2). Headache characteristics and incidence rates are not the same across the globe and age groups. Different headache types have different prevalence in different locations (3). The prevalence also changes with age and it does not increase linearly with age (4). Migraine decreases after the age 40 but secondary type headaches are more commonly seen in older people $(5,6)$. Similar to the elderly studies, headache rates in the idiopathic Parkinson Disease (IPD) patients are lower than the general population; 95\% of the IPH patients did not report any headaches (7).

In this article we aim to investigate the properties of headaches in people with IPD, which is a senile disease.

\section{Patients and Methods}

The study included people with IPD who consulted in our Parkinson disease and movement disorders policlinic that is affiliated with our neurology clinic. The patients were recruited according to the order they consulted in the clinic. People with 
Parkinson plus syndrome, those with a history of intracranial masses, aneurism, arteriovenous malformations, cerebrovascular events, and severe cranial trauma and those who were unable to answer the questions due to cognitive decline were excluded from the study. The study was approved by the Hospital Ethical Board. The patients had given their informed consents.

Sixty people who were diagnosed with IPD and who met the inclusion criteria were included in the study. A group of 100 people with similar age and sex demographics were used as controls.

Each of the Parkinson's disease patients filled out standard form in the clinic that is used to collect personal demographics (age, sex, educational level), disease information (disease duration, onset dominance, disease dominance, UPDRS scores, Hoen Yahr scores, medicine used, complications), and personal history. The headache forms surveyed the date when the headaches started, their durations, frequency, start location, localization, description of the pain, accompanying findings, triggers, auras and analgesic use.

The patients and the control group also filled out a form that collected information on age, accompanying systemic diseases and used medication.

The diagnosis of IPD was made if at least two of the symptoms bradykinesia, rigidity, rest tremor, postural instability were present. The patients were asked if they had headaches. Neurological examinations were conducted to exclude people with focal neurological abnormalities from the study. These examinations were performed by a neurology specialist who also filled out the forms.

SPSS 11.5 software package was used in the statistical evaluation. Descriptive and frequency analyses were conducted to evaluate the patient and control groups' demographic data. The data of patients with and without headaches in IPD group, as well as IPD and control groups with headache were compared using Student t-test and chi-square test.

\section{Results}

Sixty patients with IPD were included in the study. Thirty two of these patients were male $(55 \%)$ and 27 of them were female $(45 \%)$. The mean age was $65 \pm 10.85$ years (between 37 and 89 ). According to the patient reports, the mean PD duration was $4.8 \pm 4.2$ years (between 1 and 20 years).

Twenty six (43.3\%) of the IPD patients included in the study suffered from headaches. The presence of headache was determined by the positive response to the question "do you suffer from headaches".

Nineteen of these 26 patients $(73.1 \%)$ had headaches before the IPD onset. In 7 patients $(26.9 \%)$ it started after IPD.

When the patients were asked if the headaches and the disease symptoms occur at the same time, they reported that headaches could occur at any time independently from the disease symptoms.

There was no age difference between patients with or without headaches $(\mathrm{p}>0.05)$. The duration of IPD was longer in patients without headaches $(\mathrm{p}<0.05)$. Headache was more prevalent among women than men $(\mathrm{p}>0.05)$ (Table 1$)$.

In terms of their UPDRS scores, there were no significant differences $(p>0.05)$. There were no relationship between the dominant IPD symptom and headache $(\mathrm{p}>0.05)$.

When the accompanying diseases were analyzed, the rate of HT was higher in patients with headache than those without $(\mathrm{p}<0.05)$. There were no significant relationship between the Parkinson treatment used and headache $(\mathrm{p}>0.05)$. Antihypertensive treatment was significantly more in patients with headache $(\mathrm{p}<0.05)$.
There was no significant difference in Hoehn-Yahr stages between patients with or without headache $(p>0.05)$.

There was no difference in motor complications between patients with or without headache $(\mathrm{p}>0.05)$.

Idiopathic Parkinson patients were compared to the 100-person control group. Forty four of these people were female and 56 were male. The age varied between 50 and $83(62.7 \pm 8.4)$. Forty two of the patients who were taken as controls had headache. Idiopathic Parkinson disease patients and the control group were similar in terms of sex and age $(p>0.05)$. There also were no differences between the patient and control groups in terms of accompanying disorders and additional treatment $(\mathrm{p}>0.05)$

There was no significant difference between the control group and Parkinson patients in terms of the presence of headaches (p>0.05) (Table 2).

The headache types in the IPD group were episodic tension type headaches (TTH) in 16 patients $(61.5 \%)$, chronic TTH in in 6 patients $(23.1 \%)$, migraine in 1 patient $(3.8 \%)$, migraine and chronic TTH (\%3.8) in 1 patient, chronic TTH+HT-related headache in one patient $(3.8 \%)$, postherpetic neuralgia in one patient $(3.8 \%)$ (Table 3$)$.

There were no significant differences between IPD and control groups in any of the headache types $(\mathrm{p}>0.05)$. The headache types in the control group were episodic tension type headaches (TTH) in 24 patients $(57.1 \%)$, chronic TTH in in 3 patients $(7.1 \%)$, migraine in 10 patient $(23.7 \%)$, migraine and chronic TTH $(\% 4.7)$ in 2 patients, HT-related headache in 3 patient $(7.1 \%)$ (Table 3).

\section{Discussion}

From a physician's point of view, headache is the most common symptom which affects the quality of life. It does not tend to increase with age but it is an important cause of morbidity for the elderly (4). The presence of headaches in the elderly can be an indication of stroke or brain tumors and TTH and migraine are less frequently seen in these people. Secondary types of headaches such as severe HT, central nervous system diseases, metabolic abnormalities or drug-induced headaches are more common in the elderly (6).

Similarly to the old age headache studies, the prevalence of headache in the IPD population is less than the general population. Ninety five percent of the IPD patients reported not suffering from headaches (7).

In our study, $43.3 \%$ of the IPD group had headaches. In the age and sex-matched control group, this rate was $42 \%$ and there were no differences between the two groups.

When healthy controls were compared to IPD in terms of migraine attack frequency, the IPD group was found to have a lower frequency of attacks. In fact, $2 / 3^{\text {rd }}$ of the IPD patients reported that their migraine went into remission since the disease onset or completely disappeared (8). The life-time prevalence of migraine for people above 56 is $21 \%$ (9). For people over 60, the prevalence for men is $1.3 \%-15.2 \%$ and $8 \%-14 \%$ for women (10).

Table 1. The age, IPD duration and sex distribution of patients with and without headaches

\begin{tabular}{llll}
\hline & Headache & No headache & $\mathrm{p}$ \\
\hline Age & $65 \pm 10.85$ & $66.17 \pm 9.68$ & $>0.05$ \\
IPD duration & $3.5 \pm 2.74$ & $5.79 \pm 4.86$ & $<0.05$ \\
Sex (F/M) & $16 / 10$ & $11 / 23$ & $>0.05$
\end{tabular}


A hypothesis on the decreasing rate of migraine with age proposes that the nigral degeneration seen in the IPD pathophysiology affects migraine pathophysiology and prevents the precipitation of attacks. This hypothesis received partial support from studies on the substantia nigra involvement in migraine pathophysiology (11).

We detected migraine only in one patient and migraine + TTH in also in one patient in our study. Similar to the literature, our results found a lower rate of migraine in Parkinson group and higher rate in the control group. A limitation of our study, however, is the small sample size of the Parkinson patient group. When compared to the rest of literature, our results indicating a lower rate of migraine could be due to the dopaminergic changes associated with IPD rather than migraine's typical decline as a function of age.

The duration of the disease in IPD group without headaches was longer than those without. Late stage IPD did not pose a risk for headaches.

Only $23.1 \%$ of the patients with headache also had pain in the back of the neck and other patients complained about pain in other locations or wide-spread pain. Indo et al. described the morning headaches that are alleviated with L-dopa (12). In these patients who had apparent morning akinesia, it was observed that the L-dopa helps with both the Parkinson symptoms and the headaches. This type of headache where the intensity increases in parallel to the disease symptoms was not seen in our patients. In fact, according to patient reports, headaches were not concurrent to the Parkinson's symptoms and they were not correlated. Bradykinesia was dominant only in $20 \%$ of all IPD group and $70 \%$ of our patients were stage 1 in Hoehn-Yahr. While the relationship between nuchal and extremity rigidity, and headaches was not directly investigated, these findings along with those in the literature suggested that nuchal and extremity rigidity were not important factors in the etiopathogenesis of headaches in IPD.

Tension type headache is the most commonly seen headaches and its lifetime prevalence is reported to be $8 \%$ (13). In our study, TTH was more common compared to the other types. The rate of chronic TTH was higher than previously reported in IPD populations $(3,14,15)$. These higher rates of TTH can be explained by the fact that $60 \%$ of the IPD patients had psychiatric disorders (16). The most commonly seen psychiatric disorders were depression and anxiety (17). The relationship between TTH and dopamine was investigated through the efficacy of the medication used. Chlorpromazine acts as a post-synaptic dopamine antagonist in limbic system and basal

Table 2. Comparison of IPD and control group in terms of headache

\begin{tabular}{llll}
\hline & IPD & Control & p \\
\hline Headache & $26($ n) $43.3(\%)$ & $42($ n) $42(\%)$ & $>0.05$ \\
No headache & $34($ n) $56.7(\%)$ & $58($ n) $58(\%)$ & $>0.05$
\end{tabular}

Table 3 . Headache types of the groups

\begin{tabular}{lllll}
\hline & \multicolumn{3}{c}{ Parkinson } & \multicolumn{2}{c}{ Kontrol } \\
& n & $\%$ & $\mathbf{n}$ & $\%$ \\
\hline Episodic TTH & 16 & 61.5 & 24 & 57.1 \\
Chronic TTH & 6 & 23.1 & 3 & 7.1 \\
Migraine & 1 & 3.8 & 10 & 23.7 \\
Migraine + Chronic TTH & 1 & 3.8 & 2 & 4.7 \\
Chronic TTH + HT-induced & 1 & 3.8 & 3 & 7.1 \\
headache & 1 & 3.8 & - & - \\
Postherpetic neuralgia & & & &
\end{tabular}

ganglia. Chlorpromazine also has important influence on other neurotransmitter systems in addition to its antidopaminergic function. It is a strong adrenergic antagonist that affects seratonergic and histaminergic receptors. Especially the antidopaminergic effect of chlorpromazine can account of its function in migraine and TTH. It is thought that metoclopramide reduces migraine and TTH through its central antidopaminergic effect (18).

In this article, we found a similar rate of headache between the IPD group, and age and sex-matched control group. There was no difference between the headache types when compared to the control group. Even though the sample size presents a limitation of the study it is possible to say that IPD and the accompanying symptoms are not related to headaches in a positive or negative way.

\section{References}

1. Stovner LJ, Hagen K, Jensen R, Katsarava Z, Lipton R, Scher AI, Steiner TJ, Zwart J. The global burden of headache: a documentation of headache prevalence and disability worldwide. Cephalalgia 2007;27:193-210.

2. Lipton RB, Silberstein SD, Stewart WE. An update on the epidemiology of migraine. Headache 1994;34:319-328.

3. Ertas M, Baykan B, Orhan EK, Zarifoglu M, Karli N, Saip S, Onal AE, Siva A. One-year prevalence and the impact of migraine and tension-type headache in Turkey: a nationwide home-based study in adults. J Headache Pain 2012;13:147-157.

4. Hale WE, Perkins LL, May FE, Marks RG, Stewart RB. Symptom prevalence in the elderly: an evaluation of age, sex, disease, and medication use. J Am Geriatr Soc 1986;34:333-340.

5. Stewart WF, Lipton RB, Celentano DD, Reed ML. Prevalence of migraine headache in the United States.Relation to age, income, race, and other sociodemographic factors. JAMA 1992;267:64-69.

6. Hale WE, May FE, Marks RG, Moore MT, Stewart RB. Headache in the Elderly: An Evaluation of Risk Factors. Headache 1987;27:272-276.

7. Lorentz IT. Survey of headache in parkinson's disease. Cephalalgia 1989;9:83-86

8. Barbanti P, Fabbrini G, Vanacore N, Rum A, Lenzi GL, Meco G, Cerbo R Dopamine and migraine: does Parkinson's disease modify migraine course. Cephalalgia 2000;20:720-723.

9. Goebel H, Petersen-Braun M, Soyka D. The epidemiology of headache in Germany: a nationwide survey of a representative sample on the basis of the headache classiffication of the International Headache Society. Cephalalgia 1994;14:97-106.

10. Henry P, Michel P, Brochet B, Dartigues JF, Tison S, Salamon R. A Nationwide survey of migraine in France: prevalence and clinical features in adults. Cephalalgia 1992;12:229-237.

11. Castro ME, Pascual J, Romon T, Del Arco C, Del Olmo E, Pazos A. Differential distribution of $[3 \mathrm{H}]$ sumatriptan binding sites $(5-\mathrm{HT} 1 \mathrm{~B}, 5-\mathrm{HT} 1 \mathrm{D}$ and 5-HT1F receptors) in human brain: focus on brainstem and spinal cord. Neuropharmacology 1997;36:535-542.

12. Indo T, Takahashi A. Early morning headache of Parkinson's disease: A hitherto unrecognized symptom? Headache 1987;27:151-154.

13. Bigal ME, Bordini CA, Speciali JG. Intravenous chlorpromazine in the acute treatment of episodic tension-type headache. Arq Neuropsiquiatr 2002;60:537-541.

14. Zarifoglu M, Siva A, Hayran O, Selekler K, Idiman F,Sanca Y. An epidemiologic study of headache in Turkey: a nationwide survey. Neurology 1998;50(Suppl4):A225.

15. Koseoglu E, Nacar M, Talaslioglu A, Cetinkaya F. Epidemiological and clinical characteristics of migraine and tension type headache in 1146 females in Kayseri. Turkey. Cephalalgia 2003;23:381-388.

16. Schrag A. Psychiatric aspects of Parkinson's disease. An update. J Neurol 2004;251:795-804.

17. Aarsland D, Larsen JP, Lim NG, Janvin C, Karlsen K, Tandberg E, Cummings $\mathrm{JL}$. Range of neuropsychiatric disturbances in patients with Parkinson's disease. J Neurol Neurosurg Psychiatry 1999;67:492-496.

18. Cicek M, Karcioglu O, Parlak İ, Ozturk V, Duman O, Serinken M, Guryay M. Prospective, randomised, double blind, controlled comparison of metoclopramide and pethidine in the emergency treatment of acute primary vascular and tension type headache episodes. Emerg Med J 2004;21:323-326. 